\title{
Factors Affecting Green Supply Chain Operational Performance of the Thai Auto Parts Industry
}

\author{
Korrakot Yaibuathet Tippayawong *, Natananot Niyomyat, Apichat Sopadang and \\ Sakgasem Ramingwong
}

Center of Excellence in Logistics and Supply Chain Management, Faculty of Engineering, Chiang Mai University, Chiang Mai 50200, Thailand; natananot@hotmail.com (N.N.); sopadang@gmail.com (A.S.); sakgasem@gmail.com (S.R.)

* Correspondence: korrakot@eng.cmu.ac.th; Tel.: +66-5394-4185

Academic Editor: Giuseppe Ioppolo

Received: 20 September 2016; Accepted: 3 November 2016; Published: 10 November 2016

\begin{abstract}
In this work, operational performance in the green supply chain management (SCM) of the Thai auto parts industry was investigated. A green supply chain performance measurement (GSPM) model was developed from the combination of various concepts including an SCM logistics scorecard, a supply chain operations reference model, a balance scorecard, and green supply chain management. The GSPM has been designed for use as a self-evaluation tool focusing on five decisive areas, or factors, and 28 sub-factors. A factor analysis was conducted using the survey results of the GSPM in order to identify significant factors that represent the green supply chain operation performance. Grouped as three major factors, namely green procurement, green transportation, and green manufacturing; reverse logistics and eco-design; and reuse and recycle of manufacturing, their significance and impact on the auto parts industry in Thailand were highlighted. Specifically, the factor of green procurement, green transportation, and green manufacturing, as major factor 1 , in relation with the factor of reverse logistics and eco-design, as major factor 2, were found to have a strong positive relationship with the asset turnover ratio.
\end{abstract}

Keywords: supply chain management; factor analysis; financial performance; sustainable logistics

\section{Introduction}

The concept of the green supply chain was first introduced by Michigan University in 1996 with the purpose of a theoretical manufacturing supply chain. Green supply chain management (GSCM) consists of green design, clean production, and recycling technology in order to minimize the consumption of resources and energy and environmental impacts. The idea was spread and recognized throughout the manufacturing ecosystem [1-4]. GSCM has also become one of the customer preferences worldwide [5]. It has now been proved to be beneficial rather than irritating to businesses [6,7].

In some areas, GSCM is compulsory [8,9]. Otherwise, GSCM is one of the decisive strategies for business competition [10,11]. Auto parts industries in Thailand, which mostly are of tier 1, tier 2, and tier 3, are examples of those that are influenced by the GSCM trend. They must pursue GSCM to remain in place in green supply chains in the auto industry, especially with the companies that are multi-national. However, the practice is rather fuzzy and specific measurement on this GSCM is not standardized [12]. Therefore, it is the objective of this research to develop such a model to empirically evaluate the green supply chain's operational performance in the Thai auto parts industry and to identify contextual factors influencing the operational performance. The result will help in pinpointing the strengths, weaknesses, and position of firms. It will also provide possible solutions to increase operational performance via implementing GSCM in their operations. 


\section{Literature Review}

In the context of interest, the concepts of performance measurement in supply chain management, supply chain operational performance and financial performance are to be underlined as follows.

\subsection{Performance Measurement in Supply Chain Management}

Performance measurement aims at identifying information that will enable the decision maker to monitor performance, reveal progress, enhance motivation and communication, and diagnose problems. Performance measurement in SCM is mature with its development, in terms of both quantitative and qualitative indicators, including the supply chain operations reference model (SCOR Model), the balance scorecard, and the SCM logistics scorecard (LSC). The SCOR model is a measurement model focusing on four aspects: (1) planning; (2) resourcing; (3) producing; and (4) delivering. The model is widely used [13,14]. The balance scorecard is a model to identify the efficacy of the supply chain, which focuses on four aspects: (1) finance; (2) customers; (3) internal business administration; and (4) knowledge management and growth of the organization. It is outstanding in planning and visualizing the supply chain in various demeanors in business terms $[15,16]$. Both the SCOR model and the balance scorecard are recognized worldwide, but they are time-consuming and resource-excessive [17]. Because of these reasons, the LSC was then developed to minimize such limitations. When mixed with five other renowned scorecards, namely Quick Response (QR), Kurt Salmon Associates (KSA) Millennium Readiness Profile, Quick Scan (QS), Efficient Consumer Response (ECR), and Standard ECR [18], LSC encompasses 20 assessment items based on four fundamental areas: (1) corporate strategy and inter-organization alignment; (2) planning and execution capability; (3) logistics performance; and (4) Information Technology (IT) methods and implementation. The five-level descriptive rating is designed to reduce biased responses. LSC was recognized as a simple yet effective tool and was in use widely in countries including India [19] and Thailand [20], in addition to being used as a cross-country benchmark, that is, across Japan, Thailand, and China [17].

\subsection{Supply Chain Operation Performance and Financial Performance}

Financial indicators, such as cash-to-cash cycle time and return on asset, are commonly used to reflect supply chain performance [21-23]. Also, there is evidence of a correlation between GSCM and financial performance as well as customer satisfaction [24-29].

\section{Research Methodology}

\subsection{Data Collection}

The industry of interest is the Thai automotive parts industry. The auto parts industry generates more than 17 billion USD per year and is considered to be Thailand's top industry. However, the industry relies on multi-national companies as the supply chain drivers. Because of this, GSCM has become a hot issue. Out of the 189 auto parts companies in Thailand, 50 companies participated in the study. The data used in the study are based on surveys and interviews with managers and engineers of these firms. Here, the Cronbach's alpha was calculated based on the data collected, and for five decisive areas, the Cronbach's alpha of each item was found to be more than 0.9 and less than 1.0. This indicates that the data used here are reliable and consistent [30].

\subsection{Green Supply Chain Performance Measurement Model}

The GSPM model is developed based on a combination of various concepts, including LSC, the SCOR model, the balance scorecard, and GSCM. The GSPM model is constructed of 28 items, based on five decisive areas or factors, including (1) procurement; (2) transportation; (3) manufacturing; (4) reverse logistics; and (5) eco-design. Evaluation is carried out as a five-level rating with a description, according to which level 5 represents the best practice. Five factors are shown in Table 1. 


\subsection{Factor Analysis}

Factor analysis was carried out in this stage to identify the factor structure and relationship between 28 items from the respondents' point of views. The initial solution was determined using principle component analysis (PCA) with the constraint of an Eigenvalue of more than one. Varimax rotation was additionally applied to avoid multicollinearity among extracted factors since the factor scores from this approach will be utilized as input for subsequent multiple regression analysis. The result of the factor analysis is visualized. The names of those extracted factors are later assigned as group identification.

\section{Results and Discussion}

The operational performance of the green supply chain of Thai auto parts firms is of considerable interest. Questionnaires were developed, based on the GSPM model. The questionnaires were delivered in three forms, namely e-mails, interviews, and letters, to the 189 auto parts factories in Thailand. The total number of responses was 50, equivalent to $26.46 \%$ of the total number. The data yielded reliable results, with a Cronbach's coefficient alpha value of 0.960 and a Kaiser-Meyer-Olkin value of 0.763 , with a confidence of the questionnaire of $90 \%$. Moreover, the Cronbach's coefficient alpha was conducted separately on items in five decisive factors and found that the value from each group was more than 0.90 . This indicated that the items had relatively high internal consistency in each factor from the respondents' point of view. The Bartlett's test of sphericity gave an approximate chi-square value of 1074.437 , with a degree of freedom of 378.0 and a significance of 0.000 . The result indicated that variances are equal across the samples.

\subsection{Initial Green Score of Thai Auto Parts Industry}

The initial comparison of the five decisive areas yielded the results shown in Table 1. It can be seen that the scores of areas 1-3, which were mainly focused on supply chain activities, were relatively high. Meanwhile, the scores of the green perspectives, the scores of area 4 and area 5, were rather low. The initial investigation indicated that most auto parts industries in Thailand paid attention to and focused on the supply chain and manufacturing performance rather than the environmental aspects.

Table 1. Average scores of five decisive areas in Thai auto parts firms.

\begin{tabular}{lccc}
\hline Decisive Area (Factor) & Sub-Factors & Average & S.D. \\
\hline 1. Procurement & $1.1-1.9$ & 3.781 & 1.084 \\
2. Transportation & $2.1-2.5$ & 3.788 & 1.110 \\
3. Manufacturing & $3.1-3.5$ & 3.846 & 1.017 \\
4. Reverse logistics & $4.1-4.3$ & 3.203 & 1.055 \\
5. Eco-design & $5.1-5.6$ & 2.935 & 1.107 \\
\hline
\end{tabular}

\subsection{Factor Analysis}

Here, factor analysis was conducted based on the surveyed result of the GSPM in order to identify the significant factors that represent the green supply chain operation performance of Thai auto parts firms. The initial solution was determined using principal axis factoring with the constraint of an Eigenvalue of more than one. The results yielded three extracted factors. The first factor signified that 15 items were extracted with the variance rate of $37.586 \%$. The second factor signified that eight items were extracted with the variance rate of $14.573 \%$. The third factor signified that five sub-factors were extracted with the variance rate of $6.573 \%$. The results are presented in Tables 2 and 3 .

The pattern matrixes of high and low intensity factors are presented in Table 3. A value of more than 0.4 indicates a strong relationship between groups, as highlighted in the table. The following gives the definitions of these three extracted factors:

Factor 1: Green procurement, green transportation, and green manufacturing-including vendor/supplier/provider selection with environmental perspectives, transportation management, and manufacturing management with environmental perspective. 
Factor 2: Reverse logistics and eco-design-including reverse logistics management, green packaging, green facility management, employee management, green design, and green social responsibility, for instance.

Factor 3: Reuse and recycle in manufacturing-including technology, and reuse and recycle of waste and products.

Table 2. Total variance explained of three-factor extraction method based on principal component analysis.

\begin{tabular}{cccccccccc}
\hline \multicolumn{10}{c}{ Total Variance Explained } \\
\hline Extracted Factor & \multicolumn{3}{c}{ Initial Eigenvalues } & \multicolumn{2}{c}{ Extraction Sums of Squared Loadings } & \multicolumn{2}{c}{ Rotation Sums of Squared Loadings } \\
\hline & Total & $\begin{array}{c}\% \text { of } \\
\text { Variance }\end{array}$ & $\begin{array}{c}\text { Cumulative } \\
\%\end{array}$ & Total & $\begin{array}{c}\% \text { of } \\
\text { Variance }\end{array}$ & $\begin{array}{c}\text { Cumulative } \\
\%\end{array}$ & $\begin{array}{c}\text { Total } \\
\% \text { of } \\
\text { Variance }\end{array}$ & $\begin{array}{c}\text { Cumulative } \\
\%\end{array}$ \\
\hline 1 & 10.524 & 37.586 & 37.586 & 10.524 & 37.586 & 37.586 & 7.843 & 28.011 \\
2 & 4.080 & 14.573 & 52.160 & 4.080 & 14.573 & 52.160 & 5.293 & 18.904 \\
3 & 1.841 & 6.573 & 58.733 & 1.841 & 6.573 & 58.733 & 3.309 & 11.817 & 58.916 \\
\hline
\end{tabular}

Table 3. Pattern matrix —-total variance explained.

\begin{tabular}{|c|c|c|c|}
\hline \multirow{2}{*}{$\begin{array}{c}\text { Rotated Factor Matrix } \\
\text { Factor }\end{array}$} & \multicolumn{3}{|c|}{ Major Factor } \\
\hline & 1 & 2 & 3 \\
\hline 1.1 The purchased raw material can be reused or recycled. & 0.164 & -0.163 & 0.717 \\
\hline 1.2 The concern regarding the environmental management by the provider. & 0.483 & 0.182 & 0.341 \\
\hline 1.3 The concern regarding the release of carbon dioxide by the provider. & 0.819 & 0.140 & 0.254 \\
\hline $\begin{array}{l}1.4 \text { The purchased raw materials are produced from excess and environmentally } \\
\text { friendly materials. }\end{array}$ & 0.365 & -0.195 & 0.663 \\
\hline $\begin{array}{l}\text { 1.5 The purchased products are friendly to the environment, and environmentally } \\
\text { harmful products are avoided. }\end{array}$ & 0.778 & 0.122 & 0.274 \\
\hline 1.6 The packaging is manufactured from reused or recycled materials. & 0.517 & 0.076 & 0.191 \\
\hline $\begin{array}{l}1.7 \text { Computer networks are used instead of papers for marketing of products to the } \\
\text { vendor from the factory. }\end{array}$ & 0.606 & 0.025 & -0.138 \\
\hline $\begin{array}{l}\text { 1.8 The distance between the vendor and the factory is minimized in order to reduce } \\
\text { pollution and cost. }\end{array}$ & 0.715 & 0.011 & 0.287 \\
\hline 1.9 It is ensured that the provider has received ISO 9000 and ISO 14000 certificates. & 0.684 & 0.403 & 0.039 \\
\hline 2.1 The full truck load system is applied to increase the effectiveness of product delivery. & 0.801 & 0.113 & 0.101 \\
\hline 2.2 The delivery routes are determined to save fuel and reduce pollution. & 0.603 & 0.239 & 0.413 \\
\hline 2.3 Car navigator and GPS devices are installed in the product-delivering vehicles. & 0.572 & 0.202 & 0.582 \\
\hline $\begin{array}{l}2.4 \text { The factory is concerned about the fuel spent during the delivery process, and the } \\
\text { amount of released carbon dioxide is monitored. }\end{array}$ & 0.731 & 0.128 & 0.294 \\
\hline 2.5 The delivery vehicles are well checked, and maintenance plans are available. & 0.672 & 0.152 & 0.179 \\
\hline 3.1 The waste from production can be reused or recycled. & 0.244 & -0.082 & 0.791 \\
\hline 3.2 The amount of carbon dioxide released during production is minimized or managed. & 0.776 & 0.143 & 0.123 \\
\hline 3.3 The manufacturing machines frequently undergo maintenance procedures. & 0.439 & 0.227 & 0.199 \\
\hline 3.4 Pollution reducing systems are operated during the production process. & 0.581 & 0.322 & 0.179 \\
\hline 3.5 Clean manufacturing technologies are applied. & 0.720 & 0.213 & 0.132 \\
\hline 4.1 The used packaging is reused. & 0.379 & 0.468 & -0.017 \\
\hline 4.2 The waste water generated from all the facilities is neutralized and reused. & 0.287 & 0.637 & 0.072 \\
\hline 4.3 The used products sourced from customers are recycled. & 0.163 & 0.507 & 0.607 \\
\hline 5.1 The release of carbon dioxide from the factory is taken into consideration. & 0.426 & 0.670 & -0.017 \\
\hline 5.2 Environmentally friendly packaging is used. & 0.150 & 0.843 & 0.048 \\
\hline 5.3 The thought of responsibility toward the environment is instilled in every employee. & 0.093 & 0.794 & -0.269 \\
\hline 5.4 The products designed are environmentally friendly. & 0.176 & 0.855 & -0.010 \\
\hline 5.5 The wastes from all the manufacturing failures are well managed. & -0.123 & 0.765 & 0.321 \\
\hline $\begin{array}{l}5.6 \text { Communication with customers is maintained in order to make them realize the } \\
\text { importance of environmentally friendly products. }\end{array}$ & 0.145 & 0.792 & -0.095 \\
\hline
\end{tabular}

The linear regression was initially conducted between the extracted factor scores and the selected financial outcomes of the participating companies. These financial indices were considered to represent the result of management, namely asset turnover ratio, gross profit margin, and return on investment. The participants' financial data were separately obtained from the Department of Business Development, Thailand's Ministry of Commerce. This external data source is considered essential since it was argued that adoption of internal financial data from respondents alone may not sufficiently produce highly reliable results [31]. The recent financial data of three consecutive years (2012-2014) were included in this analysis. The correlation results are presented in Table 4. 
Table 4. Statistical analysis using linear regressions between score and financial indicators of auto parts industry in Thailand.

\begin{tabular}{|c|c|c|c|c|c|c|c|c|c|c|c|c|c|}
\hline \multirow{2}{*}{ Factor } & \multirow{2}{*}{ Correl-Ation } & \multicolumn{4}{|c|}{ Asset Turnover Ratio } & \multicolumn{4}{|c|}{ Gross Profit Margin } & \multicolumn{4}{|c|}{ Return on Investment } \\
\hline & & 2012 & 2013 & 2014 & Ave & 2012 & 2013 & 2014 & Ave & 2012 & 2013 & 2014 & Ave \\
\hline \multirow{2}{*}{1} & $t$ & 0.735 & 2.489 & 2.175 & 2.379 & -0.523 & -0.151 & -0.995 & -0.633 & -0.195 & 0.572 & 1.562 & 0.735 \\
\hline & $p$-value & 0.466 & 0.016 & 0.035 & 0.021 & 0.603 & 0.881 & 0.325 & 0.530 & 0.846 & 0.570 & 0.125 & 0.466 \\
\hline \multirow{2}{*}{2} & $t$ & 1.518 & 1.349 & 1.025 & 1.383 & -0.273 & -0.071 & -0.433 & -0.298 & 1.406 & 0.584 & 1.188 & 1.181 \\
\hline & $p$-value & 0.136 & 0.184 & 0.311 & 0.173 & 0.786 & 0.944 & 0.667 & 0.767 & 0.166 & 0.562 & 0.241 & 0.243 \\
\hline \multirow{3}{*}{3} & $t$ & -1.672 & -1.769 & -1.305 & -1.675 & 1.906 & 1.635 & 1.410 & 1.910 & 0.920 & 0.577 & 0.343 & 0.689 \\
\hline & $p$-value & 0.101 & 0.083 & 0.198 & 0.100 & 0.063 & 0.109 & 0.165 & 0.062 & 0.362 & 0.567 & 0.733 & 0.494 \\
\hline & $N$ & 50 & 50 & 50 & 50 & 50 & 50 & 50 & 50 & 50 & 50 & 50 & 50 \\
\hline
\end{tabular}


From Table 4, it can be concluded that the factor affecting the financial performance of auto parts industries is factor 1 which includes green procurement, green transportation, and green manufacturing. This factor has a positive correlation with only the asset turnover ratio. Meanwhile, reverse logistics and eco design, along with reuse and recycle of manufacturing, alone have no significant relationship with those selected financial indicators.

\subsection{Multiple Linear Regression Analysis between Major Factors and Asset Turnover Ratio}

Multiple linear regression analysis was used to reduce the number of variables and to measure the relationship between the asset turnover ratio and the three extracted factors. The results of the multiple linear regression analysis are presented in Table 5. The result, along with an adjusted $R^{2}$ of 0.147 , leads to the conclusion that all three major factors, without the exclusion of any major factor, have correlations with the asset turnover ratio, especially factor 1 . It was proved, again, that if one factor is excluded, the adjust $R^{2}$ reduced.

Table 5. Results of multiple linear regressions between three factors and asset turnover ratio.

\begin{tabular}{|c|c|c|c|c|c|}
\hline \multirow{2}{*}{ Model } & \multicolumn{2}{|c|}{ Unstandardized Coefficients } & \multicolumn{2}{|c|}{ Standardized Coefficients } & \multirow{2}{*}{$p$-Value } \\
\hline & Coef & StDev & Beta & $t$ & \\
\hline (Constant) & 1.548 & 0.103 & & 15.052 & 0.000 \\
\hline Factor 1: & 0.256 & 0.104 & 0.325 & 2.462 & 0.018 \\
\hline Factor 2: & 0.154 & 0.104 & 0.196 & 1.484 & 0.145 \\
\hline Factor 3: & -0.185 & 0.104 & -0.235 & -1.781 & 0.081 \\
\hline \multicolumn{6}{|c|}{$\begin{array}{l}\text { Factor 1: Green procurement, green transportation, and green manufacturing } \\
\text { Factor } 2: \text { Reverses and eco-design } \\
\text { Factor } 3: \text { Reuse and recycle in manufacturing }\end{array}$} \\
\hline \multicolumn{6}{|c|}{$R=0.446, R^{2}=0.199$, Adjusted $R^{2}=0.147$. Std. error of the estimate $=0.727$} \\
\hline
\end{tabular}

Multiple linear regression analysis was used, again, to measure the relationship between the three extracted factors to find out whether they affect the asset turnover ratio. In this stage, the scores of all three individual variables, which are between -3 and 3 , will be increased by three in order to produce positive scores (between 0 and 6). This adjustment is meant to maintain a range of scores which can represent the order of performance and also to avoid the miscalculation that could be caused by multiplication with a negative value. The results are presented in Table 6.

Table 6. Multiple linear regressions of two major factors: green procurement, green transportation, and green manufacturing and reverse logistics and eco-design to asset turnover ratio.

\begin{tabular}{cccccc}
\hline \multirow{2}{*}{ Model } & \multicolumn{2}{c}{ Unstandardized Coefficients } & \multicolumn{2}{c}{ Standardized Coefficients } & \multirow{2}{*}{$\boldsymbol{p}$-Value } \\
\cline { 2 - 5 } & Coef & Std. Error & Beta & $\boldsymbol{t}$ & \\
\hline (Constant) & 0.711 & 0.326 & & 2.184 & 0.034 \\
\hline Factor 1: & 0.256 & 0.108 & 0.325 & 2.379 & 0.021 \\
\hline Factor 2: & -0.045 & 0.564 & -0.057 & -0.079 & 0.937 \\
\hline Factor 1 $\times$ 2: & 0.052 & 0.019 & 0.356 & 2.717 & 0.009 \\
\hline Factor 1: Green procurement, green transportation, and green manufacturing \\
Factor 2: Reverse logistics and eco-design \\
\hline \multicolumn{5}{r}{$R=0.441, R^{2}=0.194$, Adjusted $R^{2}=0.177$. Std. error of the estimate $=0.907}$. \\
\hline
\end{tabular}

From the multiple linear regression analysis, it was revealed that the best adjusted $R^{2}$ of 0.177 is found when two major factors are analyzed together with the asset turnover ratio. On the other hand, 
if the comparison is made of the adjusted $R^{2}$ by neglecting the relationship, the best adjusted $R^{2}$ is observed to be 0.147 . This result reveals that determining the relationship between the factors could produce a higher adjusted $R^{2}$ value compared to determination without taking the relationship into consideration. It can be concluded here that the green procurement, green transportation, and green manufacturing factor has a positive effect on the asset turnover ratio. Moreover, it has an even better positive effect on the asset turnover ratio when scoping with reverse logistics and eco-design. Here, a non-linear effect is observed as the result of the correlation between factor 1 and factor 2 on asset turnover ratio. The relationship can be summarized in the form of the following equation.

$$
Z=0.771+0.256 x-0.045 y+0.052 x y
$$

From Equation (1), the three-dimensional function chart in Figure 1 was generated . The $X$-axis represents the score of factor 1: the green procurement, green transportation, and green manufacturing level. The $Y$-axis represents the score of factor 2: the reverse logistics and eco-design level. The $Z$-axis exhibits the asset turnover ratio. Figure 1 also illustrates the idea of the effect of factors 1 and 2 individually and the interaction between factors 1 and 2 on the asset turnover ratio.

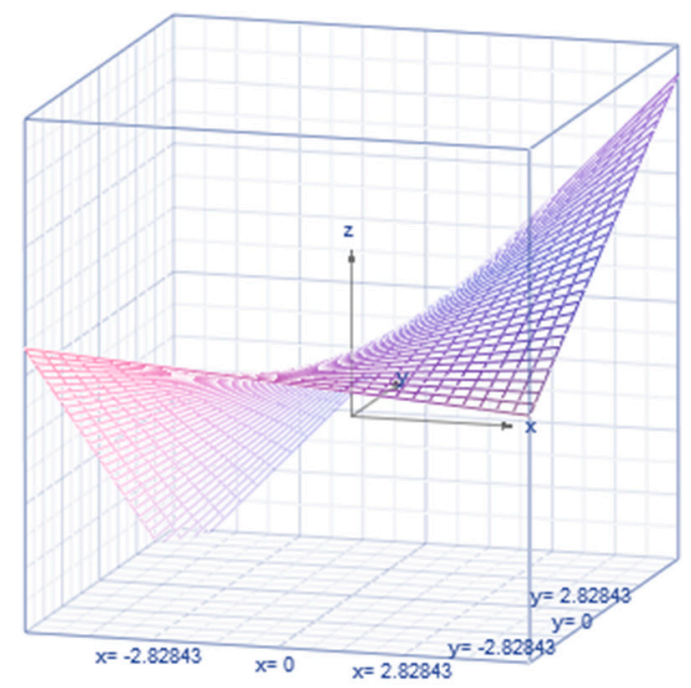

Figure 1. The three-dimensional function chart of Equation (1).

The consequence of green manufacturing combined with the eco-design concept may gain extra attention from environmentally conscious customers who, in turn, influence automobile manufacturers to demand GSCM. This segment of green customers has been increasingly expanded, leading to higher market segmentation. Hence, a combination of extracted factors 1 and 2 has a noticeable impact on the asset turnover ratio.

\section{Conclusions}

The operational performance in GSCM for 50 Thai auto parts companies was investigated and presented in this paper. The significance levels of 28 sub-factors were identified, constructing five decisive areas in GSCM. The sub-factors were grouped via factor analysis. Three extracted factors, namely factor 1: green procurement, green transportation, and green manufacturing; factor 2 : reverse logistics and eco-design; and factor 3: reuse and recycle in manufacturing, were obtained. The following list summarizes the key points of the investigation, taken from the study:

(1) Most Thai auto parts firms pay attention to and focus on the supply chain and manufacturing performance rather than the environmental aspects. 
(2) Green procurement, green transportation, and green manufacturing, as major factor 1, alone have a positive relationship with the asset turnover ratio in a linear manner.

(3) Green procurement, green transportation, and green manufacturing, as major factor 1, in relation to reverse logistics and eco-design, as major factor 2, have a strong positive relationship with the asset turnover ratio.

Previous research findings mainly focused on developing a correlation between supply chain performance and financial indicators which are the cash-to-cash cycle time and return on asset. To the authors' knowledge, none have yet related firms' financial performance with green supply chain operations. This research provided, for the first time, a direct linkage between green practices and company asset turnover ratio.

The techniques demonstrated in this work proved to be successful in evaluating and improving the supply chain of the auto parts industry. These techniques may be adopted and applied to other industries such as electronics, garments, etc. Greening their operations will certainly improve their performance and profitability.

The findings are extremely useful to the Thai auto parts firms to consider and observe if they wish to improve their financial potency or increase their asset turnover. Additionally, the GSCM database was developed, based on 50 firms, thereby yielding the average score in each of the sub-factors. This can be used as a benchmark for comparison.

Acknowledgments: This paper was funded by the Thailand Research Fund and the Commission on Higher Education, contract No. MRG5480267, and conducted under the Center of Excellence in Logistics and Supply Chain Management, Chiang Mai University, Thailand.

Author Contributions: K.Y.T, A.S. and S.R. conceived and designed the study; N.N. and K.Y.T. performed data collection and data analysis; A.S. assisted in interpreting the data; K.Y.T. and S.R. wrote the paper.

Conflicts of Interest: The authors declare no conflict of interest.

\section{References}

1. Clemens, B.; Douglas, T.J. Does coercion drive firms to adopt "voluntary" green initiatives? Relationships among coercion, superior firm resources, and voluntary green initiatives. J. Bus. Res. 2006, 59, 483-491. [CrossRef]

2. Vachon, S.; Klassen, R. Green project partnership in the supply chain: The case of the package printing industry. J. Clean. Prod. 2006, 14, 661-671. [CrossRef]

3. Arimura, T.H.; Darnall, N.; Katayama, H. Is ISO 14001 a gateway to more advanced voluntary action? The case of green supply chain management. J. Environ. Econ. Manag. 2011, 61, 170-182. [CrossRef]

4. Lun, Y.; Lai, K.H.; Ng, C.T.; Wong, C.; Cheng, T.C.E. Editorial: Research in shipping and transport logistics. Int. J. Shipp. Transp. Logist. 2011, 3, 1-5. [CrossRef]

5. Carter, C.R.; Kale, R.; Grimm, C.M. Environmental purchasing and firm performance: An empirical investigation. Transp. Res. Part E Logist. Transp. Rev. 2000, 36, 219-228. [CrossRef]

6. Wook Kim, S. Effects of supply chain management practices, integration and competition capability on performance. Supply Chain Manag. Int. J. 2006, 11, 241-248. [CrossRef]

7. Jiang, Y.; Zhou, L.-J. Study on green supply chain management based on circular economy. Phys. Procedia 2012, 25, 1682-1688.

8. Zhu, Q.; Sarkis, J.B.; Lai, K. Green supply chain management: Pressures, practices and performance within the Chinese automobile industry. J. Clean. Prod. 2007, 15, 1041-1052. [CrossRef]

9. Eltayeba, T.; Zailani, S.; Ramayah, T. Green supply chain initiatives among certified companies in Malaysia and environmental sustainability: Investigating the outcomes. J. Resour. Conserv. Recycl. 2011, 55, 495-506. [CrossRef]

10. Linton, J.D.; Klassen, R.; Jayaraman, V. Sustainable supply chains: An introduction. J. Oper. Manag. 2007, 25, 1075-1082. [CrossRef]

11. Sakis, J.; Zhu, Q.; Lai, K. An organizational theoretic review of green supply chain management literature. Int. J. Prod. Econ. 2011, 130, 1-15. [CrossRef] 
12. Srivastava, S.K. Green supply-chain management: A state-of-the-art literature review. Int. J. Manag. Rev. 2007, 9, 53-80. [CrossRef]

13. Huan, S.H.; Sheoran, S.K.; Wang, G. A review and analysis of supply chain operations reference (SCOR) model. Supply Chain Manag. Int. J. 2004, 9, 23-29. [CrossRef]

14. Gunasekaran, A.; Patel, C.; McGaughey, R.E. A framework for supply chain performance measurement. Int. J. Prod. Econ. 2004, 87, 333-347. [CrossRef]

15. Bhagwat, R.; Sharma, M.K. Performance measurement of supply chain management: A balanced scorecard approach. Comput. Ind. Eng. 2007, 53, 43-62. [CrossRef]

16. Wiersma, E. For which purposes do managers use balanced scorecards? An empirical study. Manag. Account. Res. 2009, 20, 239-251. [CrossRef]

17. Yaibuathet, K.; Enkawa, T.; Suzuki, S. Supply chain operational performance and its influential factors: Cross national analysis. J. Jpn. Ind. Manag. Assoc. 2007, 57, 473-482.

18. Arashida, K.; Enkawa, T.; Hamasaki, A.; Suzuki, S. Developing the SCM logistics scorecard and analyzing its relation to the managerial performance. J. Jpn. Ind. Manag. Assoc. 2004, 15, 95-103.

19. Bhateja, A. K.; Babbar, R.; Singh, S.; Sachdeva, A. Study of green supply chain management in the Indian manufacturing industries: A literature review cum an analytical approach for the measurement of performance. Int. J. Comput. Eng. Manag. 2011, 13, 84-99.

20. Ninlawan, C.; Seksan, P.; Tossapol, K.; Pilada, W. The implementation of green supply chain management practices in electronics industry. In Proceedings of the International Multi-conference of Engineers and Computer Scientists (IMECS), Hong Kong, China, 17-19 March 2010; pp. 17-19.

21. D'Avanzo, R.; von Lewinski, H.; van Wassenhove, L.N. The link between supply chain and financial performance. Supply Chain Manag. Rev. 2003, 7, 40-47.

22. Reiner, G.; Hofmann, P. Efficiency analysis of supply chain processes. Int. J. Prod. Res. 2006, 44, 5065-5087. [CrossRef]

23. Hendricks, K.B.; Singhal, V.R.; Stratman, J.K. The impact of enterprise systems on corporate performance: A study of ERP, SCM, and CRM system implementations. J. Oper. Manag. 2007, 25, 65-82. [CrossRef]

24. Zhu, Q.; Geng, Y.; Fujita, T.; Hashimoto, S. Green supply chain management in leading manufacturers: Case studies in Japanese large companies. Manag. Res. Rev. 2010, 33, 380-392. [CrossRef]

25. Tracey, M.; Lim, J.S.; Vonderembse, M.A. The impact of supply-chain management capabilities on business performance. Supply Chain Manag. Int. J. 2005, 10, 179-191. [CrossRef]

26. Vickery, S.K.; Jayaram, J.; Droge, C.; Calantone, R. The effects of an integrative supply chain strategy on customer service and financial performance: An analysis of direct versus indirect relationships. J. Oper. Manag. 2003, 21, 523-539. [CrossRef]

27. Raymond, P.C.; Lopez, J.; Marche, S.; Perron, G.M.; Wright, R. Influences practices and opportunities for environmental supply chain management in Nova Scotia SMEs. J. Clean. Prod. 2008, 16, 1561-1570.

28. Chien, M.K.; Shih, L.H. An empirical study of the implementation of green supply chain management practices in the electrical and electronic industry and their relation to organizational performances. Int. J. Environ. Sci. Technol. 2007, 4, 383-394.

29. Nishitani, K. An empirical study of the initial adoption of ISO 14001 in Japanese manufacturing firms. Ecol. Econ. 2009, 68, 669-679. [CrossRef]

30. Chiou, T.; Chan, H.; Lettice, F.; Chung, S. The influence of greening the suppliers and green innovation on environmental performance and competitive advantage in Taiwan. Transp. Res. Part E 2011, 47, 822-836. [CrossRef]

31. Dehning, B.; Richardson, V.J.; Zmud, R.W. The financial performance effects of IT-based supply chain management systems in manufacturing firms. J. Oper. Manag. 2007, 25, 806-824. [CrossRef]

(C) 2016 by the authors; licensee MDPI, Basel, Switzerland. This article is an open access article distributed under the terms and conditions of the Creative Commons Attribution (CC-BY) license (http://creativecommons.org/licenses/by/4.0/). 